\title{
A Desegregation Tool that Backfired: Magnet Schools and Classroom Segregation
}

\author{
Kimberly C. West
}

Magnet schools-schools offering a special curriculum and capable of attracting students of different racial backgrounds-are often touted as one of the most effective desegregation tools available. How often racial segregation occurs within such schools, however, is rarely discussed. In a successfully desegregated school, we expect to see children of various races and ethnicities learning together in the same classroom. Yet, many supposedly desegregated magnet schools operate racially segregated classrooms. ${ }^{1}$ By definition, it is paradoxical to attach the label "desegregated" to a magnet school that operates segregated classrooms. Nevertheless, the commonly accepted definition of desegregation permits a magnet school with racially segregated classrooms to be deemed desegregated.

This Note argues that courts assessing the desegregation effectiveness of magnet schools should evaluate the desegregation of classrooms as well as buildings. Part $I$, after describing magnet schools and their role in the desegregation of school systems, presents support for the claim that many magnet schools are rife with racially segregated classrooms. Racial segregation within partial-site ${ }^{2}$ magnet schools is particularly damaging to the minority students who constitute the nonmagnet portion of the school, because it labels them as inferior to the white transfer students who constitute the bulk of the magnet students within the school. Part II explains how the methods developed by academics to evaluate desegregation plans have made it possible for magnet schools to operate separate classrooms for minority and white students, yet still be considered desegregated schools. Part III describes constitutional prohibitions against racial segregation within magnet schools, but notes that federal funding programs for desegregation-oriented magnet schools do not explicitly require the Department of Education to consider how the magnet program will affect classroom racial composition. Part IV discusses the

1. As used in this Note, the term "segregated classroom" refers to a classroom that is racially identifiable and varies significantly in its racial composition from the school building, or grade level, of which it is a part. See, e.g., Vaughns v. Board of Educ., 574 F. Supp. 1280, 1315 (D. Md. 1983) (expert witness identifying a segregated classroom as one whose racial composition varies from that of school or grade level in which it is found by a plus or minus $10 \%$ variance).

2. See infra Part I.A for discussion of partial-site magnet schools. 
declining number of school desegregation cases in which the court explicitly considers within-school racial segregation. The failure of courts over the last several decades to consider classroom racial composition has resulted in desegregation plans centered around magnet schools that merely shift racial segregation from the building to the classroom level. Part IV concludes that courts should pay particular attention to classroom racial composition as they fashion equitable remedies to school segregation.

\section{Classroom Segregation IN Magnet Schools}

This Note maintains that some magnet schools, especially those structured as "partial-site" magnet schools, operate segregated classrooms. This proposition is supported by accounts of classroom segregation reported in academic literature and in the popular press ${ }^{3}$ and by individuals who have surveyed magnet schools across the country. ${ }^{4}$ This Part describes how partialsite magnet schools invariably assign their nonmagnet nontransfer (neighborhood) students to racially identifiable classrooms; how the type of magnet school included in court-ordered desegregation plans is usually of the partial-site variety; and how the fact that magnets are obliged to attract their students may lead officials administering magnet schools to implement policies which cause classroom segregation. This segregation has lead to a horrible irony: desegregation-oriented magnet schools have placed an explicit label of inferiority on the minority children they were designed to relieve.

\section{A. Magnet Schools and Their Role in Desegregation}

A "magnet school" is designed to attract students away from their neighborhood schools much as magnets attract metal objects. A distinctive school curriculum organized around a special theme or method of instruction creates the magnetic field that draws students. ${ }^{5}$ As originally conceived, magnet schools were designed to accomplish two ends: (1) to enhance students' academic performance through a distinctive curriculum and (2) to

3. See infra notes $13,28,30,40$.

4. Telephone Interview with Art Rainwater, Special Assistant to the Superintendent, Kansas City School District, Kansas City, Missouri (Apr. 20, 1993); Telephone Interview with Arthur Benson, Plaintiffs' Attorney, Missouri v. Jenkins (Apr. 27, 1993). The author attended three academic talent magnet schools: a magnet elementary school (grades K-6), a magnet middle school (grades 7-8), and a magnet high school (grades 9-12). Magnet classes at the schools were overwhelmingly composed of white students, while nonmagnet classes were primarily composed of minority students. And, irrespective of race, students in academic magnet classes were typically the product of a more privileged socioeconomic background than the nonmagnet students.

5. See, e.g., Janet R. Price \& Jane R. Stern, Magnet Schools as a Strategy for Integration and School Reform, 5 YALE L. \& POL'Y REV. 291, 292 (1987) ("The key characteristics of a magnet school are: (1) a distinctive school curriculum organized around a special theme or method of instruction; (2) voluntary enrollment elected by students and their parents; and (3) students drawn from many attendance zones."). 
enhance the school's racial and social diversity. ${ }^{6}$ Courts order the creation of magnet schools and districts implement them because magnet schools are perceived as capable of furthering the dual goals of desegregation and educational innovation. Magnet schools typically "[come] into existence as a way of meeting the terms of a court order for desegregation; they would not have been established in such numbers without that impetus, nor would they have gained political and administrative support without it."

Magnet school curricula are unique because they revolve around special themes and methods of instruction. The first magnet schools drew their themes from specialty schools such as the Bronx School of Science, Boston Latin School, and Lane Tech in Chicago, adopting areas of specialization such as science, mathematics, and performing arts. The major difference between magnet schools and specialty schools is that magnet students are generally selected as a result of their professed interest in the school rather than according to their performance on an aptitude test or during an audition. ${ }^{8}$ As interest in magnet schools has grown, an even wider range of magnet themes has developed, including "open school, alternative school, career exploration, and traditional schools, as well as other curricular themes such as health science, foreign languages, humanities, business management and computer science."

Magnet school structures generally come in two varieties: full-site magnet programs that constitute the entire school and partial-site magnet programs, where the magnet program is "an enclave in a larger regular school."10 In full-site magnets, all students are transfer students mixed together in the magnet program. ${ }^{11}$ In partial-site magnets, only part of the school is comprised of transfer students who have access to the magnet curriculum. Partial-site magnets are often placed in schools that were predominantly minority prior to desegregation efforts. The magnet portion of the school is supposed to be so enticing that it pulls white students away from their neighborhood schools to attend a formerly minority school. A partial-site magnet achieves overall building desegregation by attracting enough white transfer students to balance the number of neighborhood minority students

6. CAROL ASCHER, ERIC ClEARINGHOUSE on URBAN EdUCATION, USING MAGNET SCHOOLS FoR DESEGREGATION: SOME SUGGESTIONS FROM THE RESEARCH 3 (ERIC/CUE Trends and Issues Series No. 3, 1985), microformed on ERIC No. ED273716 (U.S. Dep't of Educ.).

7. Id. at 27 .

8. ROLF K. BLANK ET AL,, U.S. DEP'T OF EDUC., SURVEY OF MAGNET Schools: ANALYZING A MODEL FOR QUALTY INTEGRATED EDUCATION 10-11 (1983). Nevertheless, some magnet programs do have entrance criteria such as minimum grade average or minimum test score results.

9. Id. at 11 .

10. Christine H. Rossell, The Carrot or the Stick for School Desegregation Policy 55 (1990). Partial-site magnet programs are also referred to as "school-within-a-school magnets" and full-site magnets are often described as "total-school magnets." See, e.g., id. at 56; ASCHER, supra note 6, at 4.

11. Plaintiffs' Draft of Findings, Part 4, People Who Care v. Rockford Bd. of Educ., No. 89 C 20168, at 1 n.2 (N.D. Ill. filed Mar. 25, 1993) ("Full-site programs, in theory, place transfer students into a school's regular classrooms." ). 
already attending the school. Yet, partial-site magnet schools are particularly prone to segregating students within the school because the white transfer students rarely take classes with the minority nontransfer students because the two groups follow separate curriculum tracks. ${ }^{12}$ As a result, not only are the nonmagnet students denied the company of the magnet students; they are also denied the special attention, financial support, and superior educational opportunity the magnet students receive. ${ }^{13}$

Magnet schools are presently used extensively as part of court-ordered desegregation plans throughout the United States. ${ }^{14}$ Because most of these plans depend primarily on parental choice to assign students to schools and most of the partial-site magnets created under these plans are located in minority neighborhoods, ${ }^{15}$ the majority of court-endorsed magnet schools are particularly susceptible to within-school segregation. Courts may choose a desegregation plan that depends on a traditional (mandatory) student assignment method-school officials assigning students to a particular school-or may choose a plan that depends on parental/student choice as the method of assigning students to a particular school. The student assignment method can have significant effects on classroom racial composition in the magnet schools in the district. As part of desegregation plans, magnet schools are used either as occasional "sweeteners" (in magnet-mandatory assignment plans) to make the student assignments more palatable to the public or as key components (in magnet-voluntary assignment plans) designed to induce attendance choices that will create racial balance throughout the system. ${ }^{16}$

Implementing a full-site magnet school requires emptying out the soon-tobe-magnet school and filling it with all new transfer students, both majority and minority students, who have chosen the unique curriculum. Those implementing magnet-voluntary plans find this cumbersome because they do not know (or fail to consider) what to do with the minority students who need

12. See infra text accompanying notes $40-45$.

13. Plaintiffs' Draft of Findings, supra note 11, at 20 (alleging that Rockford School District's use of magnet schools has resulted in within-school segregation); David Smollar, Incoming 7th-Graders Camp Out To Stay in Gompers' Academic World, L.A. Times (San Diego County), July 11, 1989, § 2, at 3, available in LEXIS, News Library, ARCNWS File (describing partial-site magnet schools' relegation of bulk of nonwhite neighborhood students "to a different academic program, perceived as inferior by many").

14. Price \& Stern, supra note 5, at 294 (identifying Jenkins v. Missouri, 639 F. Supp. 19 (W.D. Mo. 1986), aff'd as modified, 807 F.2d 657 (8th Cir. 1986) (Kansas City) as "the most recent example of a court-ordered plan involving extensive use of magnets").

15. Districts do not usually turn white neighborhood schools into magnets because they are content to rely on minorities transferring to such schools based on the general assumption that white schools offer better educational opportunities than minority schools.

16. James S. Liebman, Desegregating Politics: "All-Out" School Desegregation Explained, 90 CoLuM. L. REV. 1463, 1649 (1990). This Note adopts the terminology employed by Christine Rossell, which distinguishes between a mandatory plan and a voluntary plan according to the degree of parental choice exercised under the plan. See RosSELl, supra note 10, at 27 ("The extent of parental choice should determine whether a plan is called 'voluntary' or 'mandatory,' . . . not the source of the order. Thus, 'board-ordered' is not synonymous with 'voluntary,' and 'court-ordered' is not synonymous with "mandatory."). 
to be replaced by white students to achieve racial balance in the minority neighborhood. ${ }^{17}$ Desegregation plans depending on student choice to assign students to particular schools (magnet-voluntary assignment plans) create far more partial-site magnet schools than plans that rely on mandatory student assignment. And no mandatory reassignment plan has been implemented in the northern United States since 1981, while only two have been implemented in the South since that time. ${ }^{18}$ As a consequence, nearly every court-ordered desegregation plan since the early 1980's has resulted in the creation of several partial-site magnet schools and only one, two, or often no full-site magnet schools. ${ }^{19}$

\section{B. Causes of Classroom Segregation in Magnet Schools}

Classroom segregation does exist in many schools that are racially balanced at the building level, ${ }^{20}$ and considerable analytic and anecdotal evidence suggests that partial-site magnet schools often operate racially imbalanced classes. ${ }^{21}$ Determining whether magnet schools create more classroom segregation than nonmagnet schools will require comparing classroom racial composition in magnet schools to that of schools desegregated by other methods. ${ }^{22}$ Empirical evidence documenting classroom segregation

17. See, e.g., ROSSEL, supra note 10 , at 56 (noting that partial-site magnet is preferred model in voluntary desegregation plans because full-site magnet schools "have serious implementation problems"). Magnet-mandatory assignment plans have no problem implementing full-site magnets because extensive cross-town reassignments are usually integral to a mandatory plan. Id. at 57.

18. Id. at xiii. Despite an ongoing scholarly battle over whether magnet-voluntary plans are more effective at desegregation than magnet-mandatory plans, school desegregation remedies with magnetvoluntary components appear to have won the war.

19. As of 1990 , Milwaukee was the only school district with more than one or two full-site magnet schools. Id. at 57 . As of $1985,21 \%$ of the Emergency School Assistance Act magnet schools receiving special federal funding because they are part of an approved desegregation plan were partial-site (schoolwithin-a-school) magnets, $11 \%$ were magnet centers, and $5 \%$ were add-on programs. AsCHER, supra note 6 , at 4 . Of the 2452 magnet programs operating during the 1992-93 school year surveyed by Magnet Schools of America, approximately $22 \%$ of the elementary magnet schools, $26 \%$ of the middle school magnet schools, and $40 \%$ of the high school magnet schools were partial-site magnets. See MAGNET SCHOOLS OF AMERICA, DIRECTORY OF PUBLIC MAGNET AND THEME BASED MAGNET SCHOOLS 1992-93: BY LEVEL AND THEME AREA (percentages based upon author's calculations).

20. See, e.g., AMERICAN FRIENDS SERVICE COMMITTEE, THE STATUS OF School Desegregation IN THE SOUTH 28-74 (1970) (cataloguing incidents of within-school discrimination including "segregated classrooms and facilities"-classroom segregation, testing, in-class segregation, segregated facilities, and segregated buses-and "racial discrimination in extracurricular activities"-discrimination in social activities, discrimination in student government and school organizations, and discrimination in athletics, cheerleading, and band); Janet Eyler et al., Resegregation: Segregation Within Desegregated Schools, in THE CONSEQUENCES OF SCHOOL DESEGREGATION 126, 126 (Christine H. Rossell \& Willis D. Hawley eds., 1983) (study examining "how the resegregation of students within desegregated schools occurs, identiffying] currently available alternatives to minimize it, and suggest[ing] directions for future research and development to meet this problem").

21. See infra text accompanying notes 30-39.

22. While there is a significant amount of academic literature on magnet schools, no body of work analyzes magnet schools in terms of their success in combatting within-school segregation. The most comprehensive studies of classroom segregation were published by James M. McPartland, P.R. Morgan, and William T. Trent in 1981. While these studies examine classroom segregation by region, educational 
in magnet schools is sparse. ${ }^{23}$ This may be due in large part to the lack of general research on classroom segregation.

The two factors repeatedly identified as causing classroom segregation within otherwise desegregated buildings are (1) methods of assigning students to academic programs, such as tracking, ability grouping, and remedial pull-out programs and (2) disciplinary practices that discriminate against minority students. ${ }^{24}$ Since magnet schools must attract their students, officials adopt practices that make their schools more enticing to the targeted parents and students-white parents and students. As part of their effort to convince whites to send the children to magnet programs, magnet school officials and teachers engage in the two practices known to cause classroom segregation-placing

level, and desegregation level, they do not include any information about the desegregation methods used to macro-desegregate the schools (i.e., desegregate the schools by building). See P.R. MORGAN \& JAMES M. MCPARTLAND, JOHNS HOPKINS UNIV. CTR. FOR SOCLAL ORG. OF SCH., THE EXTENT OF CLASSROOM SEGREGATION WITHIN DESEGREGATED SCHOOLS (1981), microformed on ERIC No. 210405 (U.S. Dep't of Educ.); WILlIAM T. TRENT \& JAMES M. MCPARTLAND, JOHNS HOPKINS UNIV. CTR. FOR SOCIAL ORG. OF SCH., RACE COMPARISONS OF STUDENT COURSE ENROLIMENTS AND EXTRACURRICULAR MEMBERSHIPS IN SEGREGATED AND DESEGREGATED HIGH SCHOOLS (1981), microformed on ERIC No. 210406 (U.S. Dep't of Educ.).

Carol Ascher has extrapolated the general discussion of within-school segregation and applied it to magnet schools; however, no one has examined whether magnet remedies, when compared to nonmagnet remedies, combat or exacerbate within-school segregation. See CAROL ASCHER, ERIC CLEARINGHOUSE ON URban EduCATION, CREATING RACIAL INTEGRATION IN A DESEGREGATED MAGNET SCHOOL 1 (1986), microformed on ERIC No. ED269518 (U.S. Dep't of Educ.); ASCHER, supra note 6, at 1.

23. "There is little research to document how successfully magnet schools create physical mixing of students of different races within school walls . . . To know how well magnet schools create genuine racial integration, we need more ethnographic research based on prolonged participation in such schools." Mary H. Metz, Magnet Schools and the Reform of Public Schooling, in CHOICE IN EDUCATION 123, 131 (William L. Boyd \& Herbert J. Walberg eds., 1990). The Magnet Schools Assistance Program administered by the U.S. Department of Education does not have the authority to keep track of the racial composition of classrooms in the magnet schools they fund. Telephone Interview with Steven L. Brockhouse, Magnet Schools Assistance Program, U.S. Department of Education (Apr. 19, 1993). Likewise, the Department of Education's Office of Civil Rights (OCR) does not collect data on classroom racial composition for all schools. Telephone Interview with Robert Moie, Office of Civil Rights, U.S. Department of Education (Apr. 19, 1993). OCR only collects classroom racial composition data on a need-to-know basis-usually for schools and districts directly involved in ability grouping litigation. Telephone Interview with $\mathrm{Dr}$. Gordon Foster, Director, Southeastern Desegregation Assistance Center, Miami Equity Associates, Inc. (Feb. 22, 1994).

24. See, e.g., Eyler, supra note 20, at 128-45; James McPartland, The Relative Influence of School and of Classroom Desegregation on the Academic Achievement of Ninth Grade Negro Students, J. SOC. ISSUES, 1969, at 93, 98; ASCHER, supra note 22, at 2. Many commentators have suggested pedagogical and policy changes to combat classroom segregation. See, e.g., KENNETH J. MEIER ET AL., RACE, CLASS, AND EduCATION: THE POLITICS OF SECOND-GENERATION DISCRIMINATION 141-48 (1989) (recommending replacing at-large elections with ward elections, recruiting more black teachers, revitalizing the powers of the Office of Civil Rights (OCR), releasing the data on teachers and administrators gathered by the Equal Employment Opportunity Commission (EEOC), eliminating or restricting academic grouping, and restructuring disciplinary actions); Norman Miller et al., Cooperative Interaction in Desegregation Settings: A Laboratory Analogue, J. Soc. IssuEs, 1985, at 63, 76-77 (suggesting that cooperative learning techniques using heterogeneous grouping techniques and multicultural educational programs be favored over academic tracking); Helen A. Moore \& Peter Iadicola, Resegregation Processes in Desegregated Schools and Status Relationships for Hispanic Students, 12 AZTLAN 39, 55 (1981) (suggesting "limiting the amounts of normreferenced testing, classroom grouping, and competition," and equalizing the burden of busing between ethnic groups); see also Robert E. Slavin, Cooperative Learning: Applying Contact Theory in Desegregated Schools, J. SOC. ISSUES, 1985, at 45. 
minority students in lower academic tracks and discriminating against minority students in meting out discipline.

One way to make magnet schools attractive to parents is by marketing them as schools for "gifted" children. Parents who perceive their children as gifted or who want their children to be gifted will be attracted to specialized classes and programs that treat their children as superior in a particular talent. Offering specialized or gifted classes to the white transfer students contributes further to the magnet-nonmagnet dichotomy that presents magnet students as more talented than nonmagnet students. ${ }^{25}$ Minority students (the victims of discriminatory school segregation) may be assigned to lower tracks than white students because officials are fulfilling their initial promise to treat the white transfer students as gifted, and because the minority students have not received compensatory educational opportunities to compensate for prior discrimination against them and their schools. ${ }^{26}$

Officials in desegregated schools tend to suspend and expel a disproportionate number of black students, with "black students suspended for offenses that would be allowed white students, or for which white students would be given lighter penalties."27 It is likely that school officials engage in even more discriminatory disciplinary practices in magnet schools as part of their effort to make the magnet school an attractive choice for white parents. Control of disciplinary problems is one of the selling points magnet schools

25. Art Rainwater provides an example of how the magnet-nonmagnet dichotomy can affect teachers' perceptions of students and their ability to take any type of magnet course:

In talking with their people [the teachers and administrators at a particular partial-site magnet school], I did not have a sense that they set out to [segregate classrooms]. There was a decided bias in terms of what kinds of kids could take what. I can remember particularly visiting one dance class, a ballet class. There was one black girl and probably fifteen white girls. We were talking to the instructor and we asked her about that and she said that typically the minority kids who came to school there did not have a good background in mathematics and were not good problem-solvers and thinkers and therefore could not take her class.

Telephone Interview with Art Rainwater, supra note 4.

A school culture in which administrators, teachers, and students lose track of the desegregation goals of the magnet program could be one such factor. According to Rosenbaum and Presser, "each child entered [Mark Twain High School (a pseudonym for the school turned into a talent theme magnet school as part of the desegregation remedy ordered in Hart v. Community School Board of Brooklyn, 383 F. Supp. 699 (E.D.N.Y.), appeal dismissed, 497 F.2d 1027 (2d Cir. 1974), aff'd, 512 F.2d 37 (2d Cir. 1975))] . . . with the understanding that he or she would receive special training in one particular area, designated as a 'talent."' James Rosenbaum \& Stefan Presser, Voluntary Racial Integration in a Magnet School, 86 SCHOOL REV. 156 (1978), reprinted in PROCEDURE 351, 356 (Robert Cover et al. eds., 1988). But, they did not enter with the understanding that desegregation was one of the magnet programs' integral goals. For instance, the talent math class, which was supposed to be an exemplary model of the magnet school success, was utterly unsuccessful in desegregating the classroom. "[T] here were almost no minority students in it. By no stretch of the imagination could it be called desegregated. This talent class had two minority students among its 25 students." Id. at 356.

26. The "Mark Twain" study showed that black and white students were not evenly distributed throughout the various talents. Only in art, instrumental music, and drama classes was the percentage of black students in a particular class close to the overall percentage of black students in the student body. Otherwise, black students were overrepresented in nonacademic talent classes and underrepresented in academic talent classes. Rosenbaum \& Presser, supra note 25, at 356.

27. ASCHER, supra note 22 , at 3. 
promote to convince white parents to send their children into the minority neighborhoods where many magnet schools are located ${ }^{28}$ Minority students may also be more susceptible to discriminatory disciplinary practices because they are in the lower and less prestigious tracks of the magnet program. School officials may focus their energy on making the school appealing to the white magnet students and their parents to keep their school building racially balanced. Discipline may be more discriminatory in magnet schools because teachers and administrators have forgotten the desegregation goals of the magnet program and have come to see minority students as "not belonging" in the school. ${ }^{29}$ Unfortunately, there have been no empirical studies testing whether magnet schools engage in more rigid tracking and more discriminatory disciplinary procedures than do nonmagnet schools.

Partial-site magnet schools are probably more likely to operate segregated classrooms than either nonmagnet or full-site magnet schools. Partial magnets exacerbate the problems that lead to classroom segregation in otherwise desegregated magnet and nonmagnet schools. Minority students may be tracked more rigidly in partial-site magnet schools where they are rarely the transfer students, under the rationale that the magnet students are traveling into the minority school to get a special education alongside other "special" students under the instruction of "special" teachers. ${ }^{30}$ Minority students may be disciplined more harshly than white students in partial-site magnets, again because they are not the magnet consumers to be pleased at these schools. ${ }^{31}$ The very fact that a partial-site magnet school is only partially magnet creates racially segregated classrooms in the nonmagnet part of the school and sometimes throughout the entire school. ${ }^{32}$ In draft findings, the plaintiffs in a recent school desegregation case suggest that the school district has implemented partial magnet programs precisely because such programs segregate students within a school:

28. See, e.g., David Smollar, Magnet Schools Are Beating Bushes for Ethnic Balance, L.A. TIMES (San Diego County), May 15, 1988, § 2, at 1, available in Westlaw, Papers Database ("[T] eacher-marketers from the inner-city schools must persuade parents that their campuses are secure and offer safe learning environments, and that drug sale and other violence ... do not affect the school.").

29. See, e.g., Rosenbaum \& Presser, supra note 25, at 357 ("The school's myth-that it existed primarily to serve the talented-led to the perception that blacks don't even belong.").

30. See, e.g., Lisa Jacques, Proposed Changes Spark Lively Comments on Magnet Programs, MIAMI TIMES, Feb. 25, 1993, at 12a, available in LEXIS, News Library, CURNWS File (quoting retired high school counselor as saying, "Sometimes children are not even allowed to socialize with magnet students .... There's also favoritism, easy schedule changes for magnet students [as] opposed to nonmagnet students and very little mixing [of the two groups] if any.").

31. Cf., e.g., Smollar, supra note 28 , at 1 ("' $[N]$ eighborhood parents-predominantly minority ... felt that bused [magnet] students were receiving more benefits than their own children, who had been ethnically isolated for years.").

32. See, e.g., People Who Care v. Rockford Bd. of Educ., No. 89-C-20168, 1992 U.S. Dist. LEXIS 11641 , at *13 (N.D. Ill. May 22, 1992) (indicating preference for full-site magnet instead of partial-site magnet in light of testimony of monitor and educators). 
After brief experience with both [partial-site and full-site magnet programs] ..., RSD [Rockford School District] quickly demonstrated that its favorite desegregation technique for white students was a partial-site alternative program, preferably one with academic or financial entrance criteria. Using this technique, groups of white students were placed in predominantly minority schools, but kept in separate programs so they had little interaction with minority students. In other words, the essence of this device was to count desegregation solely in terms of the total enrollment of a building, no matter how separate were the children in that building, both educationally and socially.

RSD's Gifted director Mr. Heideman captured the essence of this historical policy [as] ... "utilizing predominantly white children to attend a high minority impacted building to give the building a percentage balance." ...

Despite their purported "desegregation" purpose, the alternative programs were an abysmal failure in that respect. These programs created virtually all-white enclaves within black schools-independent curriculums that were totally separate from the regular academic pursuits of these predominantly black schools. For white parents who wanted a different education for their child but not within an integrated setting, this was the perfect solution. For the Rockford School District, these programs provided the veneer of "desegregation" without the actual results. Children were within the same schools, but not within the same room. All children were in the same building, but for the most part, blacks and whites lived separate lives. ${ }^{33}$

It is likely that the only opportunity nontransfer minority students and white transfer students have to interact in a partial-site magnet is on a voluntary basis between classes or during lunch periods. Thus, partial-site magnet programs "simply put white students on black campuses without integrating the classrooms., 34

Considerable anecdotal evidence points to classroom segregation in building-desegregated partial-site magnet schools. For instance, in 1987, Moton Elementary School in Perine, Florida, considered "one of the most successful magnet programs in [Dade] county,"35 had failed to desegregate its classrooms. The building was desegregated- $52 \%$ black, $38 \%$ white, and $10 \%$ Hispanic-but "in regular classrooms outside of the magnet program, 75\% of the fifth- and sixth-graders [we]re black, and $95 \%$ of the kindergartners [we]re

33. Plaintiffs' Draft of Findings, supra note 11, at 2-3.

34. De'Ann Weimer, Fate of First All Voluntary Desegregation Plan Rests with Judge, UPI, Apr. 27, 1988, available in LEXIS, Nexis Library, UPI File (describing objections of attorneys for NAACP and U.S. Justice Department to partial-site magnet programs for this reason).

35. Lourdes Fernandez, Housing Foils School Desegregation, MIAMI HERALD, Nov. 5, 1987, $\S$ Neighbors SE, at 18 , available in Westlaw, Papers Database. 
black." ${ }^{36}$ Most of the minority students at Moton experienced segregation in their classrooms. ${ }^{37}$ In a computer theme partial-magnet in Milwaukee, Wisconsin, only the 500 students participating in the magnet portion of school enjoy an integrated education while the rest of the students (the nonmagnet student body, which is predominantly minority) attend segregated classes. ${ }^{38}$ Similarly, at Enloe High School, a partial-site magnet school in Raleigh, North Carolina, there is simply an "absolute lack of integrated classrooms." 39

A study of three partial-site secondary magnet schools in Montgomery County, Maryland, revealed that the introduction of magnet schools "produc[ed] less overall classroom integration throughout the school." ${ }^{40}$ Those conducting the study found:

The magnet programs leave the racial composition of the nonmagnet students' classes largely unaffected. This is because the schedule of specialized magnet courses limits the number of opportunities for sharing classes with the rest of the student body. Where magnet and nonmagnet students do not mix in the classroom, they are mostly in classes with other high-achieving students and relatively more White students. ${ }^{41}$

The influx of transfer magnet students and the introduction of a series of courses attended primarily by the transfer students resulted in less overall classroom integration. As in other secondary schools in the county, achievement/ability grouping led to classroom racial segregation in the magnet schools. ${ }^{42}$ For the transfer students participating in the magnet program, the likelihood of experiencing increased or decreased classroom integration varied. In general, white magnet (transfer) students were likely to experience increased classroom integration while minority magnet (transfer) students were likely to experience decreased classroom integration. ${ }^{43}$ Yet, for nonmagnet

36. Id.

37. Id.

38. Telephone Interview with Art Rainwater, supra note 4.

39. Id. Rainwater (who has surveyed and visited magnet schools throughout the country) described the Enloe partial-site magnet school as follows:

As an outsider walking around (I think I visited every class on campus), it was striking - the segregation within the school itself. Although their population is almost 50-50 (certainly from the gross desegregation standpoint, it is a success), walking around the school, I was struck by Id. the absolute lack of integrated classrooms.

40. John C. Larson et al., A Microscope on Secondary Magnet Schools in Montgomery County, Maryland, in MAGNet SCHOol Policy Studies AND Evaluations 261, 265 (Donald R. Waldrip et al. eds., 1993).

41. Id. at 265 .

42. Id.

43. Id. at $287-88$ ("A combination of two factors largely explains this result. White magnet transfer students generally come from schools with higher proportions of Whites than found in the magnet schools. Also, because of their relatively high achievement levels, they would have attended, in their home schools, classes which were predominately White."). 
(nontransfer) students, the likelihood of experiencing increased classroom integration in the magnet school was minimal or nonexistent. ${ }^{44}$ Reasons for the limited opportunities for magnet and nonmagnet students to share the same classes included (1) "magnet students spen[t] considerable amounts of time in classes designed to reflect the emphasis of the magnet program," (2) "where magnet students [did] participate in courses outside their magnet specialty (for example, foreign languages and some social studies and English courses), they frequently share[d] these classes with significant numbers of magnet students due to the realities of the school scheduling process," (3) "by and large when a magnet student participate[d] in a course outside of the magnet specialty, the student [wa]s usually placed in an honors section of the course," and (4) "even when the magnet students [we]re placed in regular classes or classes which are nonacademic in focus their potential impact on the make-up of the bulk of nonmagnet classes [wa]s limited." the lack thereof) in partial-site magnet programs raises the question: "Are the resident [nonmagnet] students really in a desegregated school if they only see the opposite race magnet students for part of the day?"46

\section{The Unique Harm of Classroom Segregation in a Magnet School}

Racial segregation within a magnet school is particularly and especially objectionable because it stems from a supposed desegregation remedy. ${ }^{47}$ The fact that desegregation-oriented ${ }^{48}$ magnet schools operate separate black and white classrooms is a rueful contradiction. Worse yet, in the context of a partial-site magnet, the separation of students by race stigmatizes the bulk of the minority students attending the school as inferior to the white magnet students. This Note does not embrace the normative claim that integration or

44. Id. at 290 ("Our analyses show that there is relatively little opportunity for the mixing of magnet and nonmagnet students in classes. And, where this mixing does occur it does not contribute much to classroom interracial contact.").

45. Id. at 291-93.

46. ROSSELL, supra note 10 , at 56 .

47. Janet Eyler contends that classroom segregation is a major threat to desegregation:

[T] he separation of children by race or ethnicity within the walls of the desegregated school

... is a major threat to desegregation in that it reestablishes racial isolation that the reassignment of students from school to school was intended to eliminate. Among its consequences, [classroom segregation] undermines the possibility for interracial or interethnic contact and equal-status interactions, and denies students exposure to similar educational expectations and experiences. [Classroom segregation] thus impedes the basic goals of school desegregation: it hinders the elimination of racial stereotypes and prejudice; it delays advances in minority achievement; and it perhaps damages the chances of minorities for economic success later in life.

Eyler, supra note 20 , at 126.

48. The term "desegregation-oriented magnet school" is intended to describe magnet schools created to desegregate a school system. This term could be used to refer to school systems creating magnet schools as part of a community-driven (versus "court-driven") desegregation effort as well as school systems creating magnet schools as part of a court order to desegregate. 
interracial exposure is or should be the primary goal of desegregation, ${ }^{49}$ nor does it contend that segregated classrooms are per se harmful to minority students, white students, or both. ${ }^{50}$ This Note does, however, argue that segregated classrooms created by partial-site magnet schools in minority neighborhoods are inherently harmful.

The segregation of students within a magnet school constitutes a unique injury to minority students attending the school because it quite literally adds insult to the prior injury supposedly being remedied. The insult suffered by minority students subjected to classroom segregation in a partial-magnet school is akin to the insult described in Brown v. Board of Education. ${ }^{51}$ However, unlike the Brown insult, which the Court assumed was an internal feeling of inferiority on the part of minority students, the insult of classroom segregation in a magnet school generates an external label of inferiority that is placed squarely on minority students-the label of being a "regular" or "nonmagnet" student or a student in a lower track. With that label comes the assumption (an assumption eventually held by the teachers, magnet students of all races, and the nonmagnet students as well) that nonmagnet or lower-tracked students are less intelligent, less capable, and basically less significant than the magnet (at partial-sites) or higher-tracked students (at full-sites). ${ }^{52}$

Racial segregation within the magnet school puts minority students in a position of relative inferiority. It suggests to white and minority students alike that the separation of races is an indication of superior white ability, social importance, or academic potential. ${ }^{53}$ Irrespective of what effect integrated or segregated environments have on the self-esteem of minority students, ${ }^{54}$ it is

49. I do not believe putting minority students in a same building or room with white students is the only, nor the most effective, means of providing minority students educational opportunity equal to that of white students. See, e.g., Robert Carter, A Reassessment of Brown v. Board, in SHADES OF BROWN: NEW PERSPECTIVES ON SCHOOL DESEGREgATION 21, 27 (Derrick Bell ed., 1980) ("While we fashioned Brown on the theory that equal education and integrated education were one in the same thing, the goal was not integration but equal educational opportunity. Brown requires equal educational opportunity. If that can be achieved without integration, Brown has been satisfied."); Derrick Bell, A Model Altemative Desegregation Plan, in SHADES OF BROWN supra, at 125-39; DuBois, Does the Negro Need Separate Schools, 4 J. NEGRO EDuC. 328 (1935), reprinted in 2 THE SEVENTH SON 408 (Julian Lester ed., 1971).

50. See, e.g., Kimberle W. Crenshaw, Race, Reform, and Retrenchment: Transformation and Legitimation in Antidiscrimination Law, 101 HARV. L. REV. 1331, 1377 (1988) ("It is not separation per se that made segregation subordinating, but the fact that it was enforced and supported by state power, and accompanied by the explicit belief in African-American inferiority."). Segregation that reinforces or engenders belief in minority inferiority is certainly harmful to minority students.

51. 347 U.S. 483, 494 (1954) ("To separate [children] from others of similar age and qualifications solely because of their race generates a feeling of inferiority as to their status in the community that may affect their hearts and minds in a way unlikely ever to be undone.").

52. See, e.g., Crenshaw, supra note 50, at 1358 ("The most significant aspect of black oppression seems to be what is believed about Black Americans, not what Black Americans believe.").

53. See, e.g., Liebman, supra note 16, at 1570-71 ("[S] underlying it, that the objects of the discrimination are different .... [I]t also insists upon the permanence and visibility of the difference....".).

54. It may be less insulting or even agreeable to minority students to be segregated from students of other races if they are segregated in order to provide them with superior educational opportunities, compensating them for prior deprivation. 
insulting to minority students to be segregated by what is supposed to be a desegregation remedy or to be marginalized ${ }^{55}$ in what is supposed to be a desegregated school. The insult of being segregated by a desegregation remedy is yet more offensive when one's white peers are enjoying even greater educational opportunities than they would have in the absence of desegregation efforts and federal money to support desegregation-oriented magnet schools.

\section{DefinING EFFective DeSEgREgation}

How is it possible for magnet schools to be considered an effective desegregation tool if they fail to combat segregation within schools? Academics have typically assessed the effectiveness of a desegregation plan in terms of its success in achieving a desired building-level racial composition. Magnet schools may very well be effective tools for desegregating at the building level. ${ }^{56}$ However, magnet schools may exacerbate or even cause within-school segregation. Nevertheless, because academics have failed to evaluate desegregation plans in terms of their success in eliminating withinschool segregation, magnet schools have been deemed effective desegregation tools.

The discussion of the effectiveness of particular desegregation tools in scholarly literature has almost exclusively focused on whether voluntary or mandatory plans are more effective in combatting white flight, i.e., the diminishing numbers of white students in a school system. ${ }^{57}$ Desegregation

55. Many scholars and policymakers have criticized the desegregation initiative's failure to focus on the victims of school segregation-black children. Instead of being compensated for the injuries they suffered as a result of segregation, their needs have become ancillary. See, e.g., DERRICK BELL, AND WE ARE NOT SAVED: THE ELUSIVE QUEST FOR RACIAL JUSTICE 107 (1987) (decrying the disappearance of "all the black children" and noting that "[i]n the monumental school desegregation struggle, the intended beneficiaries had been forgotten long before they were lost") [hereinafter BELL, NOT SAVED]; Derrick Bell, Serving Two Masters: Integration Ideals and Client Interests in School Desegregation Litigation, 85 YALE L.J. 470 (1976).

56. See MARY H. METZ, DifFerent By Design: The ConTEXT AND ChaRACTER OF THREe MAGNET SCHOOLS 27-29 (1986). There is a considerable amount of literature discussing how effective magnet schools are in combatting building-level desegregation. Magnet schools have helped several school districts achieve building-level desegregation. See, e.g., Daniel U. Levine \& Eugene E. Eubanks, Desegregation and Regional Magnetization, in MAGNET SCHOOLS: RECENT DEVELOPMENTS AND PERSPECTIVES 49 (Nolan Estes et al, eds., 1990) (describing how regional magnet schools help to desegregate large public school districts, but noting potential problems associated with magnets such as student attrition and tendencies toward treating magnets as the preferred schools in a two-tiered system of magnet and regular schools); Julie A. Maloney, Note, Magnet Schools: An Attractive Desegregation Alternative, 13 J. LEGIS. 48, 57 (1986) ("Magnet schools are effective tools for desegregation."); Beth Shuster, Report: Only Magnet Schools Are Succeeding, DAILY NEwS L.A. (Valley), Jan. 20, 1989, at N1, available in Westlaw, DNLA Database (describing report saying "the magnet program is the only integration plan that is succeeding"); Michael Winerip, School Integration in Buffalo Is Hailed as a Model for U.S., N.Y. TMMES, May 13, 1985, at A1, A1, B4 ("[S]chool officials have crafted a system of magnet schools so appealing that of the 30,000 students who were bused four years ago, only 15 percent had to be ordered onto buses by the Federal judge.").

57. See, e.g., ROSSEL, supra note 10 (comparing magnet-mandatory and magnet-voluntary desegregation plans, and finding voluntary assignment magnet plans to be the most effective in achieving interracial exposure); Brian L. Fife, In Defense of Mandated School Desegregation Plans, EQurTy \& 
effectiveness has not been defined in a way that measures the degree of classroom desegregation. To date, the literature assessing desegregation plans has usually measured the level of segregation by determining the level of "racial balance." Racial balance can be measured by the Index of Dissimilarity (D) ${ }^{58}$ This index represents the percentage of black students who would have to be reassigned to white schools, if no whites were reassigned to minority schools, in order to have the same racial balance in each school as exists district-wide. An Index of Dissimilarity of zero indicates perfect racial balance-the racial composition of each school is the same as the racial composition of the district as a whole..$^{59}$

Christine Rossell, a leading desegregation expert, criticizes other desegregation experts for continuing to use "racial balance" to measure desegregation effectiveness. In lieu of racial balance, Rossell advocates measuring "interracial exposure." She argues that racial balance measures are inadequate because a desegregation outcome in which $99 \%$ of the whites have left the district but the remaining $1 \%$ are distributed evenly throughout, is considered as racially balanced as an outcome in which none of the whites have left and each school is $50 \%$ white. ${ }^{60}$ To calculate interracial exposure, "the number of minorities in each school is multiplied by the proportion [of] white[s] in the same school [and t]he result is summed for all schools and divided by the number of minorities in the school system to produce a weighted average." ${ }^{61}$ The weighted average is the percentage of white students in the average minority child's school.

EXCELLENCE, Winter 1992, at 100, 100 (concluding that mandatory plans may be more effective than voluntary plans at reducing segregation); Christine H. Rossell, The Carrot or the Stick for School Desegregation Policy?, 25 URB. AFF. Q. 474 (1990) (arguing that voluntary magnet plans will produce greater long-term interracial exposure than a mandatory magnet plans); Christine Rossell, How Effective Are Voluntary Plans with Magnet Schools?, 10 Educ. EVALUATION \& POL'Y ANALYSIS 325 (1988) (same),

58. The formula for the Index of Dissimilarity is: $D=\left[1 / 2 \Sigma\left\{b_{\imath} / b_{t}-w_{t} / w_{t}\right\}\right] \times 100$,

where

$b_{i}=$ number of black students in school ${ }_{i}$,

$b_{t}=$ total number of black students in the district,

$w_{i}=$ number of white students in school ${ }_{j}$, and

$w_{t}=$ total number of white students in the district.

Fife, supra note 57, at 102.

59. Id.

60. RoSSELL, supra note 10 , at 37 .

61. Id. at 34. Interracial exposure-the proportion of white students in the average minority child's school-is calculated as follows:

where

$$
S_{\mathrm{mw}}=\frac{\underset{k N_{\mathrm{bm}} \mathrm{P}_{\mathrm{w}}}{\Sigma}}{\mathrm{kN}_{\mathrm{km}}}
$$

$\mathrm{k}=$ each individual school

$\mathrm{N}_{\mathrm{km}}=$ the number $(\mathrm{N})$ of minorities (m) in a particular school (k)

Id.

$\mathrm{P}_{\mathrm{kw}}=$ the proportion (P) of whites (w) in the same school (k). 
Rossell claims that interracial exposure is a complete measure of the net benefits of a desegregation plan; yet, interracial exposure fails just as miserably as racial balance to measure classroom desegregation. While interracial exposure may be superior to racial balance in reflecting white flight, ${ }^{62}$ neither measure reflects resegregation by classroom. Ironically, "interracial exposure," which Rossell claims is "more closely attuned to the instrumental goal of a desegregation plan as reflected in the desegregation court cases," measure whether minority and white students are "exposed" to each other in the classroom.

Knowing how effectively a plan combats resegregation caused by white flight is important in determining a desegregation plan's overall effectiveness, but white flight is not the only cause of resegregation. School systems also experience within-school resegregation-"separation of the races within schools." ${ }^{.64}$ In order to analyze classroom desegregation, researchers need only calculate levels of classroom racial balance or classroom interracial exposure. ${ }^{65}$ Plaintiffs alleging classroom segregation have also suggested means of calculating racially identifiable classrooms. ${ }^{66}$

\section{The Goal of Desegregating Classrooms}

Classroom segregation in magnet schools may violate the Fourteenth Amendment; indeed, classroom desegregation has been identified as a goal of overall desegregation since Brown. Unfortunately, federal educational finance programs often provide funding for the very magnet schools that perpetuate within-school segregation. The statutes behind these programs, though they seem otherwise to acknowledge the need for magnets to adhere to Fourteenth Amendment standards, do not explicitly consider classroom racial composition.

Segregation within a school that is racially balanced overall may be as troubling as segregation between schools. ${ }^{67}$ For instance, within-school

62. Id. at 37 .

63. Id. at 27 .

64. Willis D. Hawley, Increasing the Effectiveness of School Desegregation: Lessons from the Research, in RACE AND SCHOOLING IN THE CITY 145, 147 (Adam Yarmolinsky et al. eds., 1981).

65. The few researchers who have studied classroom segregation have calculated classroom racial balance by inputting classroom statistics into the formula for the Index of Dissimilarity. See, e.g., 1 NATIONAL OPINION RESEARCH CTR., UNIV. OF CHI., SOUTHERN SCHOOLS: AN EVALUATION OF THE EFFECTS OF THE EMERGENCY SCHOOL ASSISTANCE PROGRAM AND OF SCHOOL DESEGREGATION 78 (1973); MORGAN \& MCPARTLAND, supra note 22; TRENT \& MCPARTLAND, supra note 22.

66. One court considered classrooms to be segregated if (1) the ratio of black students to white students in the classroom is outside the range of $25-75 \%$ in nonracially identifiable schools or (2) the racial composition of the classroom varies more than plus or minus $10 \%$ from the ratio of minority to white students in that grade level in the school. Vaughns v. Board of Educ., 574 F. Supp. 1280, 1314 n.62 (D. Md. 1983).

67. See Liebman, supra, note 16 , at 1484-1539 (dividing scholarly explanations for finding segregation objectionable into five categories according to, among other characteristics, the goals those explanations ascribe to the desegregation remedy-educational opportunity for minority students equal to that afforded white students; racial integration in and of itself; correction of the harmful effects of purposeful racial 
segregation arguably prevents students from receiving a constitutionally or morally mandated level of education. ${ }^{68}$ Similarly, within-school segregation is a barrier to a state of affairs that many individuals believe is good in and of itself - complete racial integration. And, finally, within-school segregation constitutes a failure to correct the effects of state-imposed segregation. ${ }^{69}$

Congress, the courts, and academics of various backgrounds have generally assumed that classroom desegregation will be an integral component of the more general enterprise of desegregation. ${ }^{70}$ While courts have disagreed over exactly what it means to desegregate, they have been consistent in identifying the entities they are trying to desegregate- "grades and classrooms" as well as school buildings. ${ }^{71}$ For instance, in Milliken, the Supreme Court spoke of "schools, grades, or classrooms."72 The court in Coalition To Save Our Children v. Buchanan noted classroom segregation as evidence of failure on the part of a school district to advance "toward the maximum practicable desegregation." ${ }^{\text {"73 }}$ Moreover, Congress' definition of desegregation as

discrimination; prohibition of future instances of such discrimination; and maximization of social utility).

68. See, e.g., Derrick Bell, Brown and the Interest-Convergence Dilemma, in SHADES OF BROWN, supra note 49, at 90,101 (advocating "educationally oriented remedies" with a focus on "obtaining real educational effectiveness, which may entail the improvement of presently desegregated schools as well as the creation or preservation of model black schools"); Owen M. Fiss, The Jurisprudence of Busing, 39 LAW \& CONTEMP. PROBS. 194, 200 (1975) (describing theory as to why segregation harms black students as including the proposition that "[s]egregation has the inevitable effect of reducing the financial and physical resources available to all-black schools because these schools are attended only by members of the least powerful group").

69. See, e.g., Liebman, supra note 16, at 1501 (describing "the Correction Theory").

70. See, e.g., United States v. Texas, 330 F. Supp. 235, 249 (E.D. Tex.) ("Quite clearly, it is unconstitutional to assign students to classrooms on the basis of race . . . and it should be equally clear that where the State Agency can determine ... that such discriminatory in-school assignments exist, the Agency should treat such practices as tantamount to discriminatory student assignment to schools and should act accordingly to eliminate such in-school discrimination wherever it is found."), aff'd in part and modified in part, 447 F.2d 441 (5th Cir. 1971), cert. denied sub nom. Edgar v. United States, 404 U.S. 1016 (1972). In McNeal v. Tate County School District, 508 F.2d 1017, 1019 (5th Cir. 1975), the Fifth Circuit articulated "the basic rule that classrooms which are segregated by race are proscribed regardless of the degree of overall desegregation achieved." In addition, it is common to find references to the goal of desegregated classrooms used interchangeably with the goal of desegregated schools. See, e.g., Liebman, supra note 16, at 1615 n.644 (making reference to "the conventional post-desegregation ban on within-school segregation").

71. See, e.g., Milliken v. Bradley, 418 U.S. 717, 740-41 (1974) ("[D]esegregation . . does not require any particular racial balance in each 'school, grade or classroom.") (emphasis added); Bradley v. Milliken, 345 F. Supp. 914, 918 (E.D. Mich. 1972) ("[P]upil reassignments shall be effected . . to the end that, upon implementation, no school, grade or classroom be substantially disproportionate to the overall pupil racial composition.") (emphasis added), aff'd in part and vacated in part, 484 F.2d 215 (6th Cir. 1973), rev'd on other grounds, 418 U.S. 717 (1974).

72. Milliken, 418 U.S. at 741 .

73. 744 F. Supp. 582, 590 (D. Del. 1990), modified, 757 F. Supp. 328 (D. Del. 1991). The court said its finding was supported by evidence of racial disparities at both the building and classroom level. Id. at 590 ("This disparity is also demonstrated by the composition of the two schools by classroom. As of November 1989, of the 412 classes conducted at A.I. DuPont High School, 158 (38\%) had fewer than 10\% black students, while $7(2 \%)$ had greater than $49 \%$ black students. By contrast, of the 290 classes conducted at Wilmington High School, only $3(1 \%)$ had fewer than $10 \%$ black students, while $85(29 \%)$ had more than $49 \%$ black students."). 
nondiscriminatory assignment of students applies to classrooms as well as schools. $^{74}$

\section{A. The Constitutional Standard}

In a line of cases striking down ability-grouping practices that created segregated classrooms in recently desegregated schools, the Fifth Circuit articulated the legal standard for assessing the constitutionality of student assignment methods that produce segregated classrooms. ${ }^{75}$ The $\mathrm{McNeal}$ standard, as it is known, prohibits districts that have engaged in official discriminatory action from employing student-assignment methods that result in racially segregated classrooms for a minimum period of time after the discriminatory action has ceased. ${ }^{76}$ The test is applied in order to determine when a student-assignment method resulting in classroom racial segregation is prohibited. Once a school system has complied with constitutional mandates-once it has been "unitary"77 for several years-classroom segregation is permissible under two circumstances: (1) if the system achieves "unitary status," meaning "the school district can demonstrate that its assignment method is not based on the present results of past segregation,"78 or (2) if the district can show that classroom segregation will remedy the

74. 42 U.S.C. $\$ 2000$ c(b) (Supp. IV 1992) reads:

"Desegregation" means the assignment of students to public schools and within such schools without regard to their race, color, religion, sex or national origin, but "desegregation" shall not mean the assignment of students to public schools in order to overcome racial imbalance. (emphasis added).

75. See, e.g., United States v. Gadsden County Sch. Dist., 572 F.2d 1049, 1050 (5th Cir. 1978) (affirming district court order enjoining the use of ability grouping as a method of assigning students to particular classrooms in five elementary schools); McNeal v. Tate County Sch. Dist., 508 F.2d 1017, 1021 (5th Cir. 1975) (remanding case to district court to give district opportunity to submit "some other plan not based upon race or ability grouping"); Moses v. Washington Parish Sch. Bd., 456 F.2d 1285, 1285 (5th Cir.) (affirming district court order finding that assignment of students to classrooms on the basis of standardized ability and achievement test scores violated black students' Fourteenth Amendment rights), cert. denied, 409 U.S. 1013 (1972); Lemon v. Bossier Parish Sch. Bd., 444 F.2d 1400, 1401 (5th Cir. 1971) (without ruling on the validity of testing per se, prohibiting classroom assignment on the basis of achievement test scores in a school district that has operated as unitary for only one semester); Singleton v. Jackson Mun. Separate Sch. Dist., 419 F.2d 1211, 1219 (5th Cir.) ("We pretermit a discussion of the validity per se of a plan based on testing except to hold that testing cannot be employed in any event until unitary schools systems have been established."), rev'd in part on other grounds, 396 U.S. 290 (1970).

76. McNeal, 508 F.2d at 1020-21 (barring use of ability grouping to assign students to classrooms "until the district has operated as a unitary system without such assignments for a sufficient period of time to assure that the underachievement of the slower groups is not due to yesterday's educational disparities"); Moses, 456 F.2d at 1285 (affirming district court finding that student assignment method based on standardized test scores was unlawful); Lemon, 444 F.2d at 1401 (finding assignment of students based on achievement test scores unlawful); Singleton, 419 F.2d at 1219 (barring student assignment based on achievement test scores).

77. "Despite its central role in the termination of judicial supervision and the dismantling of desegregation plans, the concept of unitary status remains unclear and the various prescriptions for how to attain it are rife with ambiguous terms." Gary Orfield \& David Thronson, Dismantling Desegregation: Uncertain Gains, Unexpected Costs, 42 EMORY L.J. 759, 762 (1993).

78. McNeal, 508 F.2d at 1020. 
results of past segregation "through better educational opportunities."79 For the purposes of applying the $M c N e a l$ standard, operating a "unitary" system is a far less stringent requirement than achieving "unitary status." A school system is "unitary" as long as it does not operate segregated schools. In order to achieve "unitary status," a school system must not only operate a unitary system but it must also "eliminate[] the vestiges of its prior discrimination and ha[ve] been adjudicated as such through the proper judicial procedures." 80

Intentional racial segregation of students by classroom is, of course, unlawful per se." "If the rule were otherwise, school districts would be permitted to resegregate students within the confines of integrated school buildings and to undermine at least part of the basic purpose of Brown $v$. Board of Education . . . ."82 Federal courts have struck down the use of intentionally discriminatory student assignment methods on the grounds that "[s]tudents must be assigned to classes, even as they must be assigned to schools, in a racially non-discriminatory fashion, and no classes may be racially identifiable." 83

Student assignment methods that result in segregated classrooms are not necessarily unconstitutional in the absence of official intent to discriminate. ${ }^{84}$ Once a school district is under court order to desegregate, however, it is prohibited from employing a classroom assignment method that results in segregated classrooms during the district's transition from a segregated system to a unitary one. An assignment program that results in segregated classrooms, irrespective of intent, "cannot be implemented until the district operates a

79. Id.

80. Georgia State Conference of NAACP v. Georgia, 775 F.2d 1403, 1414 n.12 (11th Cir. 1985). For further discussion of the distinction between operating a "unitary" system and achieving "unitary status," see infra notes $84-90$ and accompanying text.

81. See Brown v. Board of Educ., 347 U.S. 483, 495 (1954) (overturning legally compelled segregation in public schools and finding such segregation to violate Equal Protection Clause); Green v. County Sch. Bd., 391 U.S. 430, 437-38 (1968) (establishing affirmative duty of school boards to desegregate their systems).

82. Vaughns v. Board of Educ., 574 F. Supp. 1280, 1314 (D. Md. 1983) (citation omitted). The district court in Jackson v. Marvell School District considered it "settled doctrine that segregation of the races in classrooms constitut[ed] invidious discrimination in violation of the Fourteenth Amendment to the Constitution." Jackson v. Marvell Sch. Dist., 425 F.2d 211, 212 (8th Cir. 1970) (per curiam).

83. Moore v. Tangipahoa Parish Sch. Bd., 304 F. Supp. 244, 249 (E.D. La. 1969); see also Liddell v. Board of Educ., 469 F. Supp. 1304, 1335 (E.D. Mo. 1979) (finding "intact busing," assigning entire buses of minority children to the same classroom to be taught as a separate class, unlawful), rev'd on other grounds, Adams v. United States, 620 F.2d 1277 (8th Cir. 1980); United States v. Texas, 498 F. Supp. 1356, 1369 (E.D. Tex. 1980) (finding that "[t]ermination of the operation of the 'Mexican schools' was little more than technical compliance with the directive" because the district continued to effectively segregate Mexican-American elementary school students "through assignment of students to segregated classrooms"), rev'd on other grounds sub nom. United States v. Gregory-Portland Indep. Sch. Dist., 654 F.2d 989 (5th Cir. 1981).

84. Castaneda v. Pickard, 648 F.2d 989, 994 (5th Cir. 1981) (classroom segregation caused by ability grouping is permissible under certain circumstances), appeal after remand, 781 F.2d 456 (5th Cir. 1986); McNeal, 508 F.2d at 1020. Cf. Washington v. Davis, 426 U.S. 229, 240 (1976) (requiring showing of discriminatory intent as well as discriminatory impact in the context of employment discrimination). 
unitary school system for a period of at least several years." ${ }^{n 5}$ To operate a unitary system, the district cannot operate segregated schools and must comply with any court-ordered desegregation plans or decrees. ${ }^{86}$ This prohibition against classroom segregation is basically a "transitional remedial rule." Any assignment method or program resulting in segregated classrooms is per se unconstitutional during this transition period (probably around three years ${ }^{88}$ ) before the school system is unitary. During the transition period ${ }^{89}$ courts prohibit action (in this case, action resulting in classroom segregation) that would be permitted after discrimination ends or if the discrimination had never occurred..$^{90}$

If a school district is unitary for several years, it is permitted to institute student assignment programs that result in classroom segregation under certain circumstances. ${ }^{91}$ The Eleventh Circuit, applying the McNeal test, has held that achievement grouping resulting in "numerical racial disproportionality" (racially identifiable classrooms) is permissible "if the school district can demonstrate that its assignment method is not based on the present results of past segregation or will remedy such results through better educational opportunities."92

85. Georgia State Conference of NAACP v. Georgia, 775 F.2d 1403, 1413 (11th Cir. 1985) (achievement grouping "cannot be employed in any event until unitary school systems have been established"); Lemon v. Bossier Parish Sch. Bd., 444 F.2d 1400, 1401 (5th Cir. 1971) (same); Singleton v. Jackson Mun. Separate Sch. Dist., 419 F.2d 1211, 1219 (5th Cir. 1969) (same).

86. Adopting this definition of "unitary" affords the most consistent interpretation of the $\mathrm{McNeal}$ standard. See supra note 77. There is no real consensus among courts or scholars as to how to define the terms "unitary" and "unitary status." See Georgia State Conference of NAACP v. Georgia, 775 F.2d 1403, 1413 n.12 (11th Cir. 1985) ("Some confusion has been generated by the failure to adequately distinguish the definition of a 'unitary' school system from that of a school district which has achieved 'unitary status." ").

87. Paul Gewirtz, Choice in the Transition: School Desegregation and the Corrective Ideal, 86 CoLuM. L. REv. 728, 750 (1986).

88. Orfield \& Thronson, supra note 77 , at 766 .

89. The transition period is the period during which a school system changes from a dual system to a unitary system.

90. Gewirtz, supra note 87 , at $734-35$ :

During this transition period, it is not sufficient simply to prohibit new race-based decisions .... Remedial strategies and transformative actions are appropriate to remove the effects of past discrimination. As a result, during the transition courts may prohibit actions that would be permitted in the racial end-state, require actions that would be prohibited or at most permitted in the end-state, and permit actions that would be impermissible in the end-state.

91. McNeal v. Tate County Sch. Dist., 508 F.2d 1017, 1020 (5th Cir. 1975). According to the McNeal court:

School districts ought to be, and are, free to use such grouping whenever it does not have a racially discriminatory effect. If it does cause segregation, whether in classrooms or in schools, ability grouping may nevertheless be permitted in an otherwise unitary system if the school district can demonstrate that its assignment method is not based on the present results of past Id. at 1020 .

segregation or will remedy such results through better educational opportunities.

92. Georgia State Conference of NAACP v. Georgia, 775 F.2d 1403, 1414 (11th Cir. 1985) (quoting McNeal, 508 F.2d at 1020), (emphasis added); see also Irene P. ex rel. Debra P. v. Turlington, 730 F.2d 1405, 1414 (11th Cir. 1984) (invoking the McNeal test to assess the validity of a diploma sanction and concluding that the use of the SSAT-II test as a diploma sanction would be permissible only if the state demonstrated "either (1) that the disproportionate failure of blacks was not caused by the present effects 


\section{B. Applying the McNeal Standard to Magnet Schools}

Some classroom segregation in magnet schools is the result of school officials' intentional structuring of magnet programs to segregate students by classroom. For instance, school districts may purposefully structure magnet programs to minimize contact between minority students and white students by systematically rejecting full-site magnets and implementing partial-site programs, or by physically segregating white students from minority students by placing the magnet program in a separate part of the school or in a separate building. ${ }^{93}$ The plaintiffs in a pending case in Rockford, Illinois, contend that the Rockford School District has a history of using magnet schools to segregate within school buildings. ${ }^{94}$ The intentional use of certain magnet structures to separate neighborhood (minority) students and magnet (white) students clearly violates the Equal Protection Clause because such segregation is the result of intentionally discriminatory action on the part of school officials.

The legal standard is different in cases where school officials, intending to use magnet schools as desegregation tools, segregate students within the magnet school. Unintentional classroom segregation is not per se unconstitutional. ${ }^{95}$ Thus, magnet school structures that result in segregated classrooms are not per se unconstitutional. However, in cases where the

of past intentional segregation, or (2) that the use of the test as a diploma sanction would remedy those effects); United States v. Gadsden County Sch. Dist., 572 F.2d 1049, 1051-52 (5th Cir. 1978) (per curiam) (invoking the $\mathrm{McNeal}$ test to assess validity of ability grouping resulting in segregated classrooms, specifically "a concentration of white students in the upper sections and black students in the lower levels").

93. Another example of actions on the part of school officials that suggest intent to use magnet schools to segregate is the establishment of a separate "minority" gifted program to perpetuate segregation within the gifted program, and the district's refusal to adopt any policy for promoting within-school integration. See, e.g., Plaintiffs' Draft of Findings, supra note 11, at 33-34 (describing the creation of the Pilot Gifted Program, a "minority" gifted program, despite the existence of a "regular" gifted program that was almost completely. white, as presenting to students, staff, and the community "a highly invidious and false distinction between white students who were 'really gifted,' and black students who even at their best were not capable of being gifted").

94. The plaintiffs' findings in this case depict the school system as using magnet programs to keep white students and minority students separate. A parent whose child attended the gifted theme magnet in Rockford described the magnet program as a means of keeping students segregated within the school:

[The] [g]ifted program fulfilled its unspoken promise to whites that the program would not be "subject to" interaction with neighborhood students. In her deposition, Eleanor Brown described interaction between white parents and teachers of the gifted program . . . “. . I actually heard parents say, "you better not put my kids with those other kids." In particular she mentioned a function put on by the school [parent-teacher organization], "the night that I actually went and actually saw the performance where the kids were separated. . ." Ms. Brown also noted that she felt the separation of gifted and non-gifted students exacted a psychological toll on children, and that's why she removed her daughter from the program. "Academic-wise, yes, they will say they did it for this reason or that reason, but as far as the children, I think the negative is definitely there emotionally for them, and maybe not for white children but for black children." Id. at $39-40$.

95. See McNeal v. Tate County Sch. Dist., 508 F.2d 1017, 1020 (5th Cir. 1975) (finding classroom segregation caused by ability grouping "may nevertheless be permitted in an otherwise unitary system if the school district can demonstrate that its assignment method is not based on the present results of past segregation or will remedy such results through better educational opportunities"). 
magnet school is part of a court-ordered desegregation remedy, it is a desegregation tool; thus, classroom segregation within magnet schools that takes place before the school system is unitary is constitutionally prohibited under the McNeal standard. Even after a school district has met the requirements of its desegregation order (i.e., even after it is unitary), it is prohibited from operating magnet programs with classroom segregation unless it passes the second part of the McNeal test-(1) it "can demonstrate that its [classroom] assignment method is not based on the present results of past segregation (i.e., it achieves unitary status) or (2) it can demonstrate [that the assignment method with disparate racial impact] will remedy [the] results [of past segregation] through better educational opportunities." 96

\section{Magnet School Assistance Statutes}

Magnet schools that are not part of a court-ordered desegregation plan may not be subject to the $\mathrm{McNeal}$ standard. ${ }^{97}$ However, within-school segregation in magnet schools receiving supplemental funding arguably contradicts the desegregation-oriented purpose of federal magnet school assistance statutes. The federal statute providing additional grant money for magnet schools conditions an agency's eligibility on whether it is part of a desegregation plan ordered by a court, state agency, or state official, or a plan approved by the U.S. Secretary of Education as adequate under 42 U.S.C. $\$ 2000 \mathrm{~d}^{98}$ and

96. Georgia State Conference of NAACP v. Georgia, 775 F.2d 1403, 1414 (11th Cir. 1985) (quoting McNeal, 508 F.2d at 1020) (emphasis added); see also supra note 92.

97. Thus, racial segregation within magnets implemented outside the context of desegregation litigation may need to be challenged on the same constitutional grounds plaintiffs have used to challenge ability grouping schemes with disparate racial impact. See, e.g., Castaneda v. Pickard, 781 F.2d 456, 458 (5th Cir. 1986) (plaintiffs claiming discriminatory ability grouping "resulted in impermissible classroom segregation").

98. In order to qualify for state or federal funding, magnet schools must often (1) be part of a districtwide desegregation plan and (2) prevent, reduce, or eliminate racial isolation. Under the federal Magnet Schools Assistance Program, a local educational agency implementing a magnet school is eligible for federal assistance if the agency:

(1) is implementing a plan undertaken pursuant to a final order issued by a court of the United States, or a court of any State, or any other State agency or official of competent jurisdiction, and which requires the desegregation of minority group segregated children or faculty in the elementary and sccondary schools of such an agency; or

(2) without having been required to do so, has adopted and is implementing, or will, if assistance is made available to it under this subchapter, adopt and implement, a plan which has been approved by the Secretary as adequate under title VI of the Civil Rights Act of 1964 [42 U.S.C. $2000 \mathrm{~d}$ et seq.] for the desegregation of minority group segregated children or faculty in such schools.

20 U.S.C. $\S 3022$ (1988).

The articulated purpose of the federal Magnet Schools Assistance Program is to support by means of financial assistance:

(1) the elimination, reduction, or prevention of minority group isolation in elementary and secondary schools with substantial portions of minority students; and

(2) courses of instruction within magnet schools that will substantially strengthen the knowledge of academic subjects and the grasp of tangible and marketable vocational skills of students attending such schools. 
whether it assures the Department of Education that "it will not engage in discrimination based upon the race, religion, color, national origin, sex, or handicap of students to schools or to courses within schools of such agency except to carry out the approved plan." ${ }^{.99}$ Adequate desegregation of schools under 42 U.S.C. $\S 2000 \mathrm{c}$ has been defined by Congress to require desegregation "within such schools." federal courts have implicitly and explicitly made classroom segregation a goal of the overall desegregation effort suggests that magnet schools with segregated classrooms should not be eligible for such financial assistance. ${ }^{101}$ Yet, schools applying for federal magnet school funding are not required to demonstrate explicitly that their proposed magnet program will achieve withinschool desegregation. The Department of Education defines "desegregation" under the Magnet Schools Assistance Program as:

a plan for the reassignment of children or faculty to remedy the illegal separation of minority group children or faculty in the schools of an LEA [local educational agency] or a plan for the reduction, elimination, or prevention of minority group isolation in one or more of the schools of an LEA. ${ }^{102}$

"Minority group isolation" as defined by the Department of Education bears no relationship to classroom racial composition whatsoever. Minority group isolation "means a condition in which minority group children constitute more than 50 percent of the enrollment of the school."103 Viewed alone, "desegregation," as defined under the federal Magnet Schools Assistance Program, would not appear to encompass classroom desegregation. Having failed to define "minority group isolation" in the Magnet School Assistance Act, ${ }^{104}$ yet indicating its intent to assist schools engaged in desegregation as defined under 42 U.S.C. $\$ 2000 c,{ }^{105}$ Congress has not made it clear whether

20 U.S.C. § 3023 (1988); see, e.g., Marilyn Musumeci et al., New York State Magnet School Evaluation Study, in MAGNET SCHOOL POLICY STUDIES, supra note 40, at 97, 115 (describing the four basic requirements for magnet school funding in New York as (1) "A district must be named in the State Legislature's allocation of funds to districts for the purpose of planning or implementing a magnet school or schools;" (2) "A school must be developed in concert with a district-wide desegregation plan acceptable to the Commissioner of Education;" (3) "A school's program must provide a special curriculum not generally offered in the district;" and (4) "The program must prevent, reduce, or eliminate racial isolation in any magnet school which deviates from the district-wide enrollment of students.").

99. 20 U.S.C. $\$ 3027$ (b)(4) (1988) (emphasis added).

100. See supra note 74 .

101. See supra notes $70-74$.

102. 34 C.F.R. $\$ 280.4$ (1993).

103. Id. (emphasis added).

104. 20 U.S.C. $\$ \$ 3021-3032$ (1988).

105. Again, Congress rests eligibility for magnet school assistance on whether the agency requesting funds is implementing a desegregation plan. If the agency is voluntarily adopting a desegregation plan, the plan must have been "approved by the Secretary [of Education] as adequate under title VI of the Civil Rights Act of 1964 [42 U.S.C. 2000 d et seq.] for the desegregation of minority group segregated children." 20 U.S.C. $\$ 3022$ (1988). 
a desegregation-oriented magnet school that does not reduce (and may even increase) minority group isolation within particular schools is eligible for this special federal funding. Congress has a responsibility to ensure that federal money does not worsen the racial apartheid that exists within so many school systems today. The Magnet School Assistance Program should be amended to override the Department of Education's regulations and to incorporate a measure of classroom racial composition in the definition of "minority group isolation."

\section{FAILURE TO QUESTION MAgNETS}

Recent years have witnessed a decline in the number of courts explicitly demanding classroom as well as building desegregation. Earlier in the school desegregation initiative, it was more common for courts to argue that segregated classrooms impede the basic goals of school desegregation and that a desegregated school should not operate segregated classrooms. ${ }^{106}$ Since then, school desegregation cases have continued to involve claims that defendants have discriminated against minority students by maintaining segregated classrooms in otherwise desegregated schools. ${ }^{107}$ However, fewer and fewer courts have explicitly prohibited "racially identifiable" classrooms and required school officials to report on classroom racial composition. ${ }^{108}$

106. A Louisiana district court found it "erroneous" to consider a school with a totally black first grade class and a totally white first grade class desegregated solely because the schools "taught children of both races":

A school composed of white classes and black classes is not desegregated. Students must be assigned to classes, even as they must be assigned to schools, in a racially non-discriminatory fashion, and no classes may be racially identifiable. This does not of course prevent the classification of students by any criteria that are not racially discriminatory.

Moore v. Tangipahoa Parish Sch. Bd., 304 F. Supp. 244, 249 (E.D. La.), appeal dismissed, 421 F.2d 1407 (5th Cir. 1969).

107. See, e.g., Castaneda v. Pickard, 781 F.2d 456, 458 (5th Cir. 1986) (plaintiffs claiming discriminatory ability grouping "resulted in impermissible classroom segregation"); Christian v. Board of Educ., 440 F.2d 608, 610 (8th Cir. 1971) (describing plaintiffs' motion to have defendants cited for contempt "on the assumption that [the new desegregation plan] contemplated segregated classes at the 'desegregated' school facilities"); Montgomery v. Starkville Mun. Separate Sch. Dist., 665 F. Supp. 487, 492 (N.D. Miss. 1987) (plaintiffs alleging that defendants "have discriminated against black school children by maintaining segregated classes"), aff'd, 854 F.2d 127 (5th Cir. 1988); Georgia State Conference of NAACP v. Georgia, 99 F.R.D. 16, 19 (S.D. Ga. 1983) (plaintiffs claiming "black children have been tracked into racially malapportioned classrooms in otherwise integrated schools"), aff'd in part, rev'd in part, and remanded, 775 F.2d 1403 (11th Cir. 1985); Vaughns v. Board of Educ., 574 F. Supp. 1280, 131314 (D. Md. 1983) (plaintiffs contending "students are assigned to classrooms in a way which makes a large number of . . . classrooms racially identifiable"); Chase v. Twist, 323 F. Supp. 749, 751 (E.D. Ark. 1970) (plaintiffs claiming defendants are "continuing their policy, practice, custom and usage of maintaining segregated classrooms" and "that the classes within the schools are substantially segregated by race").

108. Desegregation court orders issued in the 1960's, 1970's, and early 1980's prohibited racially identifiable classrooms and discriminatory classroom assignment procedures. These orders also required school superintendents to report classroom racial composition to the courts. See, e.g., Carter v. School Bd., 569 F. Supp. 568, 572 (M.D. La. 1983) (ordering the school system to "adopt non-discriminatory standards for the assignment of students . . . to classrooms" and to report "[t]he total number of students, by race, enrolled in each class section by grade and subject per class section"); Moore v. Tangipahoa Parish Sch. Bd., 304 F. Supp. 244, 252-53 (E.D. La. 1969) ("All classroom assignments shall be made on a racially 
Twenty years ago, the district court in Hart v. Community School Board ${ }^{109}$ declared within-school segregation illegal and noted that "[s]o far as the children are concerned, such internal segregation is even more invidious than segregation by schools, since it is impossible to ignore what is observable each day." 110 In the late 1960's, the court in Hobson v. Hansen ${ }^{111}$ found that "physical separation from those in other tracks"112 is unlawful when the tracking system that creates the physical separation is "founded on socioeconomic and racial status rather than ability." 113 One of the few recent cases involving magnet plans that did consider classroom desegregation was Diaz v. San Jose Unified School District. ${ }^{114}$ The court in Diaz ordered the desegregation monitor to observe "the racial balance of classrooms to determine whether a significant number of classes are racially imbalanced, and advis[e] the court whether students in 'self-contained" ${ }^{115}$ [gifted and talented magnet] programs are racially isolated from other students in the host schools." 116

However, in recent years, judicial evaluation of the desegregation effectiveness of magnet schools, like the evaluation by desegregation experts, has generally been limited to building-level desegregation. For instance, the court in Tasby v. Estes ${ }^{117}$ endorsed the magnet school approach as the plan that promised to be "most effective," 118 without considering whether the magnet approach would desegregate classrooms. ${ }^{119}$ The court in United States v. Board of Education of Chicago ${ }^{120}$ also took the typical approach in its analysis of magnet schools. Its opinion is replete with factual findings

non-discriminatory basis and in such a manner that no class is racially identifiable. ... The Superintendent of Schools shall report to the court, opposing counsel, and the Educational Resource Center on School Desegregation ... the number of students by race assigned to each classroom in each grade for all schools ...."), appeal dismissed, 421 F.2d 1407 (5th Cir. 1969); Smith v. St. Tammany Parish Sch. Bd., 302 F. Supp. 106, 109-10 (E.D. La. 1969) (same), amended, 316 E. Supp. 1174 (E.D. La. 1970), aff'd, 448 F.2d 414 (5th Cir. 1971); Moses v. Washington Parish Sch. Bd., 302 F. Supp. 362, 366-67 (E.D. La. 1969) (same).

109. 383 F. Supp. 699 (E.D.N.Y.), appeal dismissed, 497 F.2d 1027, 1029 (2d Cir. 1974), aff'd, 512 F.2d 37 (2d Cir. 1975).

110. Id. at 740 .

111. 269 F. Supp. 401 (D.D.C. 1967), cert. dismissed, 393 U.S. 801 (1968), remanded on other grounds sub nom. Smuck v. Hobson, 408 F.2d 175, 190 (D.C. Cir. 1969).

112. Id. at 512 .

113. Id.

114. 633 F. Supp. 808 (N.D. Cal. 1986), aff'd, 861 F.2d 591 (9th Cir. 1988).

115. A school which operates a "self-contained" magnet program is operating a partial-site magnet. See infra Part I.A.

116. Diaz, 633 F. Supp. at 824.

117. 412 F. Supp. 1192 (N.D. Tex. 1976), remanded, 572 F.2d 1010 (5th Cir. 1978).

118. Id. at $1205 \mathrm{n} .50$ ("The mandate of the Supreme Court is to adopt the plan which promises realistically to be most effective and after our experience...., this Court is of the opinion that a magnet school approach will accomplish this goal.").

119. Id. at 1205 (articulating belief "that the magnet school concept on the 9-12 grade level will be more effective than the assignment of students to achieve a certain percentage of each race in each high school [building]" without discussing what concept will be most effective in avoiding racially identifiable classrooms).

120. 621 F. Supp. 1296 (N.D. Ill. 1985). 
evaluating building-level racial composition, but does not discuss classroom racial composition or the goal of preventing racially identifiable classrooms. Evaluating the effectiveness of magnet schools, one district court concluded that " $[t]$ he case law reveals that the "utility and propriety of magnets as a desegregation remedy is beyond dispute." been entirely uncritical of magnet schools, their reasons for rejecting magnetbased desegregation plans have not stemmed from concern about racial segregation within magnet schools. ${ }^{122}$

If bringing together students of different racial groups is one of the goals of a magnet school, as it is certainly a goal of desegregation, evaluating the effectiveness of magnet schools in terms of how many students learn in desegregated classrooms is crucial. Hence, both the courts deciding and the social scientists testifying in school desegregation cases should evaluate magnet schools based upon this criterion.

\section{CONCLUSION}

The same reasoning that led the Court to reject the freedom-of-choice desegregation plan implemented by the New Kent County School Board in Green v. County School Board, ${ }^{123}$ the first major case in which the Supreme Court discussed the substantive requirements of a desegregation remedy, ${ }^{124}$ arguably requires courts to reject magnet-based desegregation plans that result in segregated classrooms. Green requires a desegregation "plan that promises to work."125 A magnet school structure that segregates students by classrooms cannot be said to "work" in the sense that Green requires, even if it achieves building-level racial balance. According to the Court in Green, if a desegregation tool "fails to undo segregation, other means must be used to achieve this end." 126 If the segregation that must be undone is classroom segregation as well as building-level segregation, magnet structures which result in segregated classrooms should be rejected in favor of other

121. Coalition To Save Our Children v. Board of Educ., 757 F. Supp. 328, 352 (D. Del. 1991) (quoting Liddell v. Missouri, 731 F.2d 1294, 1310 (8th Cir.), cert. denied sub nom. Leggett v. Liddell, 469 U.S. 816 (1984)).

122. Id. (describing reasons other courts rejected desegregation plans involving magnets: (1) "the plan lacked attendance and enrollment guidelines to ensure its effectiveness," (2) "the plan allowed one-race schools to continue where other plans involving mandatory techniques would leave fewer or no one-race schools," and (3) "the plan was at most a concept which showed no sign of careful planning or serious intent.").

123. 391 U.S. 430 (1968).

124. Gewirtz, supra note 87 , at 735 .

125. Green v. County Sch. Bd., 391 U.S. 430,439 (1968) ("The burden on a school board today is to come forward with a plan that promises realistically to work, and promises realistically to work now.")

126. Id. at 440 (quoting Bowman v. County Sch. Bd., 382 F.2d 326, 333 (4th Cir. 1967) (concurring opinion)). 
desegregation tools more likely to eliminate segregation at both the classroom and building levels. ${ }^{127}$

The crucial point is that while magnet remedies may provide whatever benefits accrue from students going to school in the same building, it is very possible "to integrate schools and segregate classrooms using magnet programs." 128 In hopes of preventing magnet schools from being employed as a segregative desegregation tool, this Note seeks to encourage courts to make explicit factual findings examining whether magnet schools, especially partial-site magnet schools, effectively desegregate classrooms. If some magnets do not, which is the likely conclusion, the federal courts must reassess their conclusion that magnet-based voluntary assignment desegregation plans are the most effective desegregation tool available.

127. Green notes that courts have "not merely the power but the duty to render a decree which will so far as possible eliminate the discriminatory effects of the past as well as bar like discrimination in the future." Id. at 438 n.4 (quoting Louisiana v. United States, 380 U.S. 145, 154 (1965)). Likewise, if the school board adopts a desegregation plan which is less "effective" than another available method, Green "places a heavy burden upon the board to explain its preference for an apparently less effective method." Id. at 439. Hence, courts have a duty to identify which magnat structures are better or worse at combatting classroom segregation or which nonmagnet structures might be more successful at overcoming classroom segregation. Given the close connection between partial-site magnets and voluntary plans, magnetmandatory plans might be less likely than magnet-voluntary plans to cause significant classroom segregation. Instead of rejecting magnet schools or magnet-voluntary desegregation plans altogether, implementing certain pedagogical structures such as "cooperative learning" (a teaching methodology which minimizes ability grouping) may be a way of making a magnet-dependent desegregation plan "work" in the sense of minimizing classroom segregation. See, e.g., Joyce L. Epstein, After the Bus Arrives: Resegregation in Desegregated Schools, J. SOC. IssuES, 1985, at 23; Carol J. Mills \& Ame E. Tangherlini, Finding the Optimal Match: Another Look at Ability Grouping and Cooperative Learning, EQUITY \& EXCELLENCE, Winter 1992, at 205.

128. Mark Kriegel, Magnet Program Questioned; Mills Says Board's Plan Won't Integrate Suncoast, MiAmi Herald (Palm Beach), Jan. 14, 1988, at 1PB, 1PB, available in Westlaw, PAPERSMJ Database (Palm Beach County Superintendent admitting "classroom segregation is a risk" in implementing magnet programs). 